Original article

\title{
Synthesis and Identification of a new class of antileukemic agents containing 2-(arylcarboxamide)-(S)-6-amino-4,5,6,7-tetrahydrobenzo[d]thiazole
}

\author{
D.S. Prasanna ${ }^{\mathrm{a}, 1}$, C.V. Kavitha ${ }^{\mathrm{b}, 1}{ }$, K. Vinaya ${ }^{\mathrm{a}}$, S.R. Ranganatha ${ }^{\mathrm{b}}$, Sathees C. Raghavan ${ }^{\mathrm{b}}$, K.S. Rangappa ${ }^{\mathrm{a}, *}$ \\ ${ }^{a}$ Department of Studies in Chemistry, University of Mysore, Manasagangotri, Mysore-570 006, India \\ ${ }^{\mathrm{b}}$ Department of Biochemistry, Indian Institute of Science, Bangalore- 560 012, India
}

\section{A R T I C L E I N F O}

\section{Article history:}

Received 27 July 2010

Received in revised form

20 August 2010

Accepted 25 August 2010

Available online 19 September 2010

\section{Keywords:}

Tetrahydrobenzo[d]thiazole

Cytotoxicity

Apoptosis

Cancer therapeutics

Leukemia

\begin{abstract}
A B S T R A C T
Recently we have reported the effect of (S)-6-aryl urea/thiourea substituted-2-amino-4,5,6,7-tetrahydrobenzo[d]thiazole derivatives as potent anti-leukemic agents. To elucidate further the Structure Activity Relationship (SAR) studies on the anti-leukemic activity of (S)-2,6-diamino-4,5,6,7-tetrahydrobenzo[d]thiazole moiety, a series of 2-arlycarboxamide substituted-(S)-6-amino-4,5,6,7-tetrahydrobenzo[d]thiazole were designed, synthesized and evaluated for their anti-leukemic activity by trypan blue exclusion, 3-(4,5-dimethylthiazol-2-yl)-2,5-diphenyltetrazolium bromide (MTT), lactate dehydrogenase (LDH) assays and cell cycle analysis. Results suggest that the position, number and bulkiness of the substituent on the phenyl ring of aryl carboxamide moiety at 2nd position of 6-amino-4,5,6,7-tetrhydrobenzo[d]thiazole play a key role in inhibiting the proliferation of leukemia cells. Compounds with ortho substitution showed poor activity and with meta and para substitution showed good activity.
\end{abstract}

(C) 2010 Elsevier Masson SAS. All rights reserved.

\section{Introduction}

Leukemias are uniformly fatal diseases of unknown aetiology characterized by excessive and abnormal proliferation of primitive white blood cells and their precursors with infiltration into the various tissues of the body. Leukemias occur in people of all ages. The leukemias of childhood are the more common one and these are the cancers of the hematopoietic system, involving in most cases, malignant transformation of lymphoid progenitor cells and less commonly transformation of myeloid progenitor cells.

Thiazole moieties are having various pharmacological activities, in general like cyclin dependent kinase inhibitors [1,2], CCR antagonists [3,4], adenosine receptor antagonists [5-8], anti-inflammatory [9] and antibacterial activities [10]. There are many reports available on the anti-cancer activity of 2-aminothiazole and benzothiazole derivatives [11-17]. $\quad N$-(2-Chloro-6-methylphenyl)-2-[[6-[4-(2hydroxyethyl)-1-piperazinyl]-2-methyl-4-pyrimidinyl]-amino)]-1,3thiazole-5-carboxamide (BMS-354825, dasatinib, SPRYCEL ${ }^{\circledR}$ ) is a novel multi-targeted kinase inhibitor recently approved in several countries for the treatment of chronic myelogenous leukemia (CML) as well as Philadelphia chromosome-positive acute lymphocytic leukemia (ALL). Dasatinib exhibits greater

\footnotetext{
* Corresponding author. Tel.: +91 821 2515149; fax: +91 8212500846.

E-mail addresses: rangappaks@chemistry.uni-mysore.ac.in, rangappaks@gmail. com (K.S. Rangappa).

1 Both the authors contributed equally.
}

potency than imatinib mesylate $\left(\right.$ Gleevec $^{\circledR}$ ) and inhibits the majority of kinase mutations in imatinib-resistant CML [18-21].

In our laboratory, we have synthesized a series of $1-((S)-2-$ amino-4,5,6,7-tetrahydrobenzo[d] thiazol-6-yl)- 3-(substituted phenyl)-thiourea and urea derivatives by coupling amine at position 6 of (S)-2,6-diaminotetrahydrobenzo[d]thiazole with different substituted aryl isothiocyanates and isocyanates and identified them as potent anti-leukemic agents [22,23]. We continued to seek alternative templates by converting the amine at position 2 of $(S)$ 2,6-diaminotetrahydrobenzo[d]thiazole to amide functionality and to check their efficacy as anti-leukemic agents.

\section{Chemistry}

We synthesized a series of novel class of $2-N$-( substituted phenyl) carbonyl substituted 2,6-diamino-4,5,6,7-tetrahydrobenzo [d] thiazol hydrochloride derivatives $\mathbf{4}(\mathbf{a}-\mathbf{h})$ and evaluated the antileukemic activity of these derivatives. Synthesis of $\mathbf{4}(\mathbf{a}-\mathbf{h})$ was done as outlined in Scheme 1 . The key intermediate (S)-2,6-diamino4,5,6,7-tetrahydrobenzo[d]thiazole $\mathbf{1}$ was synthesized using the earlier reported method [24]. Compound 1 on treatment with Boc anhydride in presence of potassium carbonate using tetrahydrofuran as solvent at -5 to $0{ }^{\circ} \mathrm{C}$ yielded the mono amino protected compound 2. This mono protected compound on treatment with different aryl substituted acid chlorides in presence of triethylamine using dichloromethane as solvent gave compounds $\mathbf{3}(\mathbf{a}-\mathbf{h})$. These 
<smiles>[R]c1ccc(C(=O)Nc2nc3c(s2)C[C@@H](NC(=O)OC(C)(C)CC#CCC#CC)CC3)cc1</smiles><smiles>[R]c1ccc(C(=O)Nc2nc3c(s2)C[C@@H](N)CC3)cc1</smiles>

Reagents and conditions: i) Boc anhydride, $\mathrm{K}_{2} \mathrm{CO}_{3}$, THF, -5 to $0{ }^{\circ} \mathrm{C}$; ii)Acid chloride, Triethyl amine, Dichloromethane: iii) $\mathrm{HCl}$ in Ether
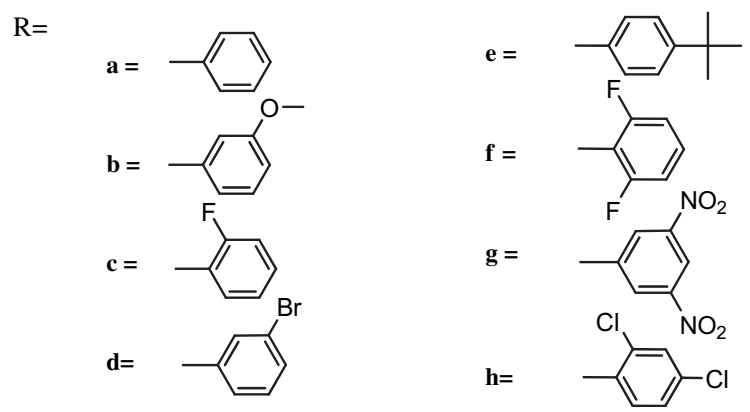

Scheme 1. Synthesis of 2-(arylcarboxamide)-(S)-6-amino-4,5,6,7-tetrahydrobenzothiazole derivatives.

compounds on deprotection of boc protection using $\mathrm{HCl}$ in ether yielded the hydrochloride salts of the desired compounds $4(\mathbf{a}-\mathbf{h})$. The synthesized novel compounds were characterized using the IR, ${ }^{1} \mathrm{H}$ NMR, LCMS and elemental analysis data.

\section{Pharmocology}

The human leukemia cells, K562 and CEM were selected for the purpose of preliminary anti-cancer screening of newly synthesized compounds. To assess the cytotoxicity, we employed trypan blue dye exclusion assay, MTT assay, LDH assay and cell cycle analysis. For this, cells growing in log phase were treated with different concentrations $(10,50$ and $100 \mu \mathrm{M})$ of 4,5,6,7-tetrahydrobenzo[d] thiazole derivatives $\mathbf{4}(\mathbf{a}-\mathbf{h})$. Further, cytotoxicity compound $\mathbf{4 e}$ on the growth of normal cells was assessed using 293T cells (human embryonic kidney epithelial cells) using MTT assay.

\section{Results and discussion}

\subsection{Chemistry}

The structure of compound 2 was confirmed by missing of peak corresponding to amine at position 6 of tetrahydrobenzothiazole and the presence of peak corresponding to Boc protected - $\mathrm{NH}$ and a singlet peak corresponding to 9 tert-butyl protons of Boc in the $1 \mathrm{H}$ NMR spectrum of compound 2. The structures of compounds 4 (a-h) were confirmed by the absence of $-\mathrm{NH}_{2}$ peak around $\delta 6.5$ ppm corresponding to the amine at position 2 of tetrahydrobenzo[d]thiazole and the presence of a peak around $\delta 12.5 \mathrm{ppm}$ corresponding to amide proton in the ${ }^{1} \mathrm{H}$ NMR spectrum of the final compounds and a strong absorption at $3395-3435 \mathrm{~cm}^{-1}$ for $-\mathrm{NH}$ and $1670-1690 \mathrm{~cm}^{-1}$ for $\mathrm{C}=\mathrm{O}$ in the IR spectrum of the compounds along with the LCMS and elemental analysis data confirmed the structure of the novel compounds $4(a-h)$.

\subsection{Biology}

Newly synthesized 4,5,6,7-tetrahydrobenzo[d]thiazole derivatives $\mathbf{4}(\mathbf{a}-\mathbf{h})$ were assessed for cytotoxicity against two human leukemia cell lines, K562 and CEM. The effective concentrations of these derivatives required to inhibit K562 or CEM cell growth and survival were determined first by carrying out dose response experiments using trypan blue dye exclusion assay. In this assay, the cells were counted at intervals of $24 \mathrm{~h}$ till the control cells attained stationary phase (data not shown). The cell viability was further assessed by MTT assay. The exposure of these derivatives at various concentrations for different time points decreased the number of live cells in a concentration and time dependent manner. Among the compounds $\mathbf{4}(\mathbf{a}-\mathbf{h})$, compounds $\mathbf{4 b}, \mathbf{4 d}, \mathbf{4 e}, \mathbf{4 g}$ and $\mathbf{4 h}$ showed good inhibition against $\mathrm{K} 562$ cells with $\mathrm{IC}_{50}$ values of $17.88 \mu \mathrm{M}, 21.01 \mu \mathrm{M}, 4.52 \mu \mathrm{M}, 8.16 \mu \mathrm{M}$ and $7.72 \mu \mathrm{M}$, respectively and for CEM cells the corresponding $\mathrm{IC}_{50}$ values were $13.78 \mu \mathrm{M}$, $22.82 \mu \mathrm{M}, 4.52 \mu \mathrm{M}, 9.02 \mu \mathrm{M}$ and $8.72 \mu \mathrm{M}$ respectively (Table 1 ). The other compounds namely $\mathbf{4 a}, \mathbf{4 c}$ and $\mathbf{4 f}$ exerted moderate inhibitory activity.

Table 1

$\mathrm{IC}_{50}$ values of tetrahydrobenzo[d]thiazole derivatives determined by MTT assay.

\begin{tabular}{lll}
\hline & $\mathrm{IC} 50($ in $\mu \mathrm{M})$ & \\
\cline { 2 - 3 } Compound & $\mathrm{K} 562$ & $\mathrm{CEM}$ \\
\hline $\mathbf{4 a}$ & 65.73 & 61.35 \\
$\mathbf{4 b}$ & 17.88 & 13.78 \\
$\mathbf{4 c}$ & 57.23 & 56.62 \\
$\mathbf{4 d}$ & 21.01 & 22.82 \\
$\mathbf{4 e}$ & 4.52 & 4.52 \\
$\mathbf{4 f}$ & $>100$ & 81.24 \\
$\mathbf{4 g}$ & 8.16 & 9.02 \\
$\mathbf{4 h}$ & 7.72 & 8.72 \\
\hline
\end{tabular}


In our previous studies we reported that the nature of the substituent on the phenyl group of 1-((S)-2-amino-4,5,6,7-tetrahydrobenzo[d]thiazol-6-yl)-3-(substituted phenyl)-thiourea and urea derivatives playing a key role in the anti-leukemic activity of these compounds $[22,23]$. Electron withdrawing groups on the phenyl ring of the aryl thiourea/urea moiety showed potent activity. Here, in these compounds $\mathbf{4}(\mathbf{a}-\mathbf{h})$, we observed that the position and size of the substituent on the phenyl ring of aryl carboxamide playing the key role. Comparing the $\mathrm{IC}_{50}$ values of the newly synthesized derivatives $\mathbf{4}(\mathbf{a}-\mathbf{h})$, we were able to draw some of the structure activity relationships (SAR). Compound $\mathbf{4 a}$, which is having unsubstituted phenyl ring showed moderate activity with an $\mathrm{IC}_{50}$ value of $65.73 \mu \mathrm{M}$ against $\mathrm{K} 562$ cells and $61.35 \mu \mathrm{M}$ against CEM cells. Compound $\mathbf{4 c}$ with 2-fluoro substitution on phenyl ring also showed moderate activity with an $\mathrm{IC}_{50}$ value of $57.23 \mu \mathrm{M}$ against $\mathrm{K} 562$ cells and $56.62 \mu \mathrm{M}$ against CEM cells. Compound $\mathbf{4 f}$ having 2,6-difluoro substitution showed poor activity with $\mathrm{IC}_{50}$ values of $>100 \mu \mathrm{M}$ for K562 cells and $81.24 \mu \mathrm{M}$ for CEM cells.

Compounds $\mathbf{4 b}$ and $\mathbf{4 d}$ having methoxy and bromo substitution respectively at the meta position on the phenyl ring showed good activity. The corresponding $\mathrm{IC}_{50}$ values are $17.88 \mu \mathrm{M}$ and $21.02 \mu \mathrm{M}$ respectively for $\mathrm{K} 562$ cells and 13.78 and $22.82 \mu \mathrm{M}$ respectively for CEM cells. Comparing the activity of $\mathbf{4 b}$ and $\mathbf{4 d}$ with that of compounds $\mathbf{4 c}$ and $\mathbf{4 f}$, we observed that, the position of the substitution is playing a key role in the inhibitory activity.

Compound $\mathbf{4 g}$ having a meta dinitro (3,5-dinitro) substitution showed good activity with $\mathrm{IC}_{50}$ values of $8.16 \mu \mathrm{M}$ and $9.02 \mu \mathrm{M}$ respectively for $\mathrm{K562}$ and CEM cells. The activity of compound $\mathbf{4 g}$ is good compared to that of compounds $\mathbf{4 b}$ and $\mathbf{4 d}$ with mono methoxy and mono bromo substitution at meta positions respectively. This may be due to the substitution at meta position and also the presence of the bulkiness of nitro group.

Compound $\mathbf{4 h}$ having ortho and para dichloro substitution also showed good activity with $\mathrm{IC}_{50}$ values of $7.72 \mu \mathrm{M}$ and $8.72 \mu \mathrm{M}$ respectively for K562 and CEM cells which is comparable with that of compound $\mathbf{4 g}$ with meta dinitro substitution. Even though the chloro group is small compared to nitro groups, the activity may be due to the presence of chloro at ortho position.

Compound $\mathbf{4 e}$ having a tert-butyl substitution at para position showed more potent and better activity compared to all other molecules in the series. Since we observed the complete death of cells at $10 \mu \mathrm{M}$ of $\mathbf{4 e}$, we tested at low concentrations to determine the $\mathrm{IC}_{50}$ value and it was found to be $4.52 \mu \mathrm{M}$ for both the cell lines (data not shown). The effect of $\mathbf{4 e}$ on cell viability was also a concentration and time dependent manner like other molecules in the series tested. The potency of this molecule could be due to the bulkiness of the tert-butyl group. Further, to investigate the cytotoxicity of $\mathbf{4 e}$ we carried out LDH release assay, which is an indicator of cell death at early time point of $24 \mathrm{~h}$ at low concentrations (Fig. 1). The data showed that $4 \mathbf{e}$ induces the release of $\mathrm{LDH}$ into the media in a concentration dependent manner.

In addition, the results from trypan blue exclusion assay and MTT assay showed that $\mathbf{4 e}$ significantly reduced the number of live cells. Hence, to explore the effect of $\mathbf{4 e}$ on cell cycle distribution of $\mathrm{K} 562$ cells, we studied cell cycle distribution by fluorescence activated cell sorting (FACS). The histogram of vehicle control (DMSO) treated cells showed a standard cell cycle pattern, which include G1 and G2 peaks separated by $S$ phase peak (Fig. 2). G0/G1 peak (mostly dead cells) was either absent or not prominent. Although we were not able to visualize the prominent arrest at any stage of the cell cycle, we noted the accumulation of subploid cells, the subG1 phase (G0/G1), and decline of both $\mathrm{G} 1$ and G2/M (Fig. 2A and B) phases at $10 \mu \mathrm{M}$ when compared with untreated cells. We did not see prominent changes in any phase of cell cycle at low concentrations and our studies suggest that significant growth inhibition by $\mathbf{4 e}$ could be due to apoptosis.

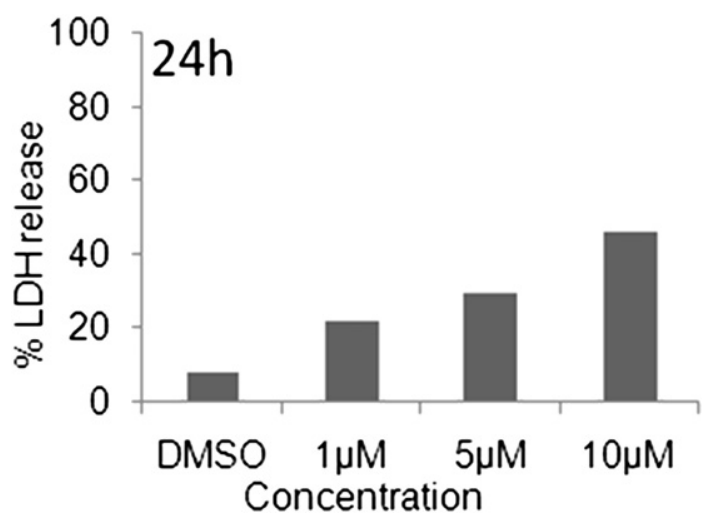

Fig. 1. Time- and dose-dependent LDH release in K562 cells treated with 4e. K562 cells were incubated for $24 \mathrm{~h}$ with different concentrations of $4 \mathbf{e}$. Release of LDH in the medium was measured at $490 \mathrm{~nm}$. Results are presented as percentage of LDH release.

Further, to determine the cytotoxic effect of $4 \mathbf{e}$ on normal cells, 293T cells (human embryonic kidney epithelial cells) were treated with $4 \mathbf{e}$ at different concentrations $(1-5 \mu \mathrm{M})$ and viability of cells was determined by MTT assay. Data reveals that $4 \mathbf{e}$ has no significant effect on normal cells at tested concentrations (Fig. 3).

\section{Conclusions}

From the structure activity relationship studies, we observed that the position and number of the substituents on the phenyl ring of aryl carboxamide moiety in the tetrahydrobenzothiazole derivatives $\mathbf{4}(\mathbf{a}-\mathbf{h})$ are important in reasoning the activity. Compounds with no substitution and/or ortho substitution are shown poor inhibition of proliferation of leukemia cells, whereas the compounds with meta and para substitution the reasonable inhibiting the proliferation of leukemia cells. Bulky substituents at the meta and ortho position also play a dominant role in inhibiting the leukemic cells proliferation.

\section{Experimental Section}

IR spectra were recorded using a Jasco FTIR-2008 series. ${ }^{1} \mathrm{H}$ NMR spectra were recorded on Shimadzu AMX 400-Bruker, $400 \mathrm{MHz}$ spectrometer using DMSO as a solvent and TMS as internal standard (chemical shift in $\delta \mathrm{ppm}$ ). Spin multiplets are given as $\mathrm{s}$ (singlet), $\mathrm{d}$ (doublet), $\mathrm{t}$ (triplet) and $\mathrm{m}$ (multiplet). Mass and purity were recorded on an LC-MSD-Trap-XCT. Elemental (CHNS) analyses were obtained on Vario EL III Elementar. Silica gel column chromatography was performed using Merck 7734 silica gel (60-120 mesh) and Merck made TLC plates.

\subsection{Synthesis of 2-(arylcarboxamide)-(S)-6-amino-4,5,6,7- tetrahydrobenzothiazole derivatives}

\subsubsection{Synthesis of (S)-tert-butyl 2-amino-4,5,6,7-tetrahydrobenzo [d]thiazol-6-ylcarbamate 2}

To the solution of compound (S)-2,6-diamino-4,5,6,7-tetrahydrobenzo[d]thiazol 1 (3 g, $0.018 \mathrm{~mol}$ ) in tetrahydrofuran, potassium carbonate ( $4.9 \mathrm{~g}, 0.035 \mathrm{~mol})$ was added followed by Boc anhydride $(3.8 \mathrm{~g}, 0.0175 \mathrm{~mol})$ dropwise at $-5^{\circ} \mathrm{C}$ and stirred at -5 to $0{ }^{\circ} \mathrm{C}$ for $6 \mathrm{~h}$. Completion of reaction was monitored using TLC. After completion of reaction, tetrahydrofuran was removed under reduced pressure. Water was added and the reaction mixture was extracted thrice using ethyl acetate $(3 \times 50 \mathrm{~mL})$. The combined organic layer was dried over anhydrous sodium sulphate. Ethyl acetate was removed under reduced pressure and purified using silica gel (60-120 mesh) using 
A

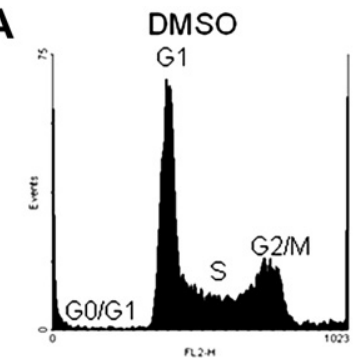

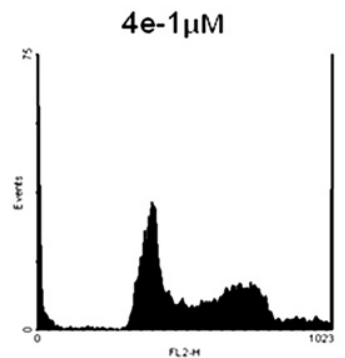
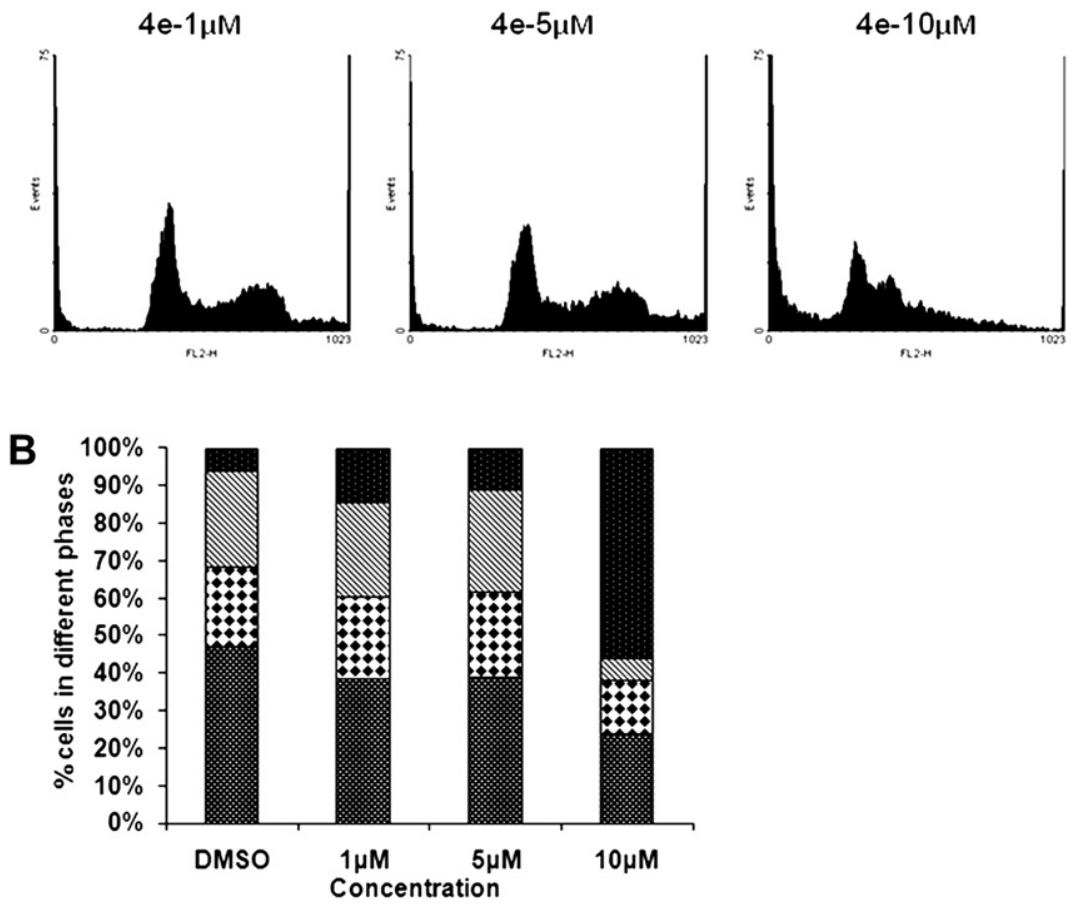

G1 $\nabla S \otimes G 2 / M=G 0 / G 1$

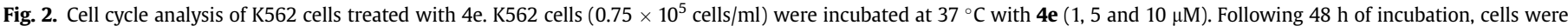

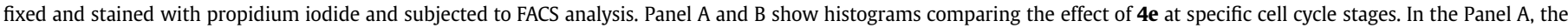
first histogram represents DMSO treated cells. Panel B show the quantification of cells in different stages of cell cycle followed by treatment with $\mathbf{4 e}$.

1:1 hexane: ethyl acetate as eluent. Yield $4.5 \mathrm{~g}(95 \%) .{ }^{1} \mathrm{H}$ NMR (DMSO$\left.d_{6}, 400 \mathrm{MHz}\right) \delta: 6.94(\mathrm{~d}, 1 \mathrm{H}, \mathrm{NH}), 6.65\left(\mathrm{~s}, 2 \mathrm{H}, \mathrm{NH}_{2}\right), 3.63(\mathrm{bs}, 1 \mathrm{H},-\mathrm{CH}-)$, $2.70\left(\mathrm{~m}, 1 \mathrm{H},-\mathrm{CH}_{2}-\right), 2.56\left(\mathrm{~m}, 2 \mathrm{H},-\mathrm{CH}_{2}-\right), 2.37\left(\mathrm{~m}, 1 \mathrm{H},-\mathrm{CH}_{2}-\right), 1.86$ $\left(\mathrm{t}, 1 \mathrm{H},-\mathrm{CH}_{2}-\right), 1.37\left(\mathrm{~s}, 9 \mathrm{H},-\left(\mathrm{CH}_{3}\right)_{3}\right)$. Elemental Analysis: Found: $\mathrm{C}$, $53.63 ; \mathrm{H}, 7.06$; N, 15.52; $\mathrm{S}, 12.01$; Calculated for $\mathrm{C}_{12} \mathrm{H}_{19} \mathrm{~N}_{3} \mathrm{O}_{2} \mathrm{~S}$ : C, 53.51; $\mathrm{H}, 7.11 ; \mathrm{N}, 15.60 ; \mathrm{S}, 11.90$.

6.1.2. General procedure for the synthesis 2-N-aryl carbonyl substituted 2,6-diamino-4,5,6,7-tetrahydrobenzo[d]thiazol hydrochloride $4(a-h)$

To a solution of tert-butyl (S)-2-amino-4,5,6,7-tetrahydrobenzo [d]thiazol-6-ylcarbamate 2 (1 eq) in dichloromethane, triethylamine ( 3 eq) was added and cooled to $0^{\circ} \mathrm{C}$, respective acid chlorides

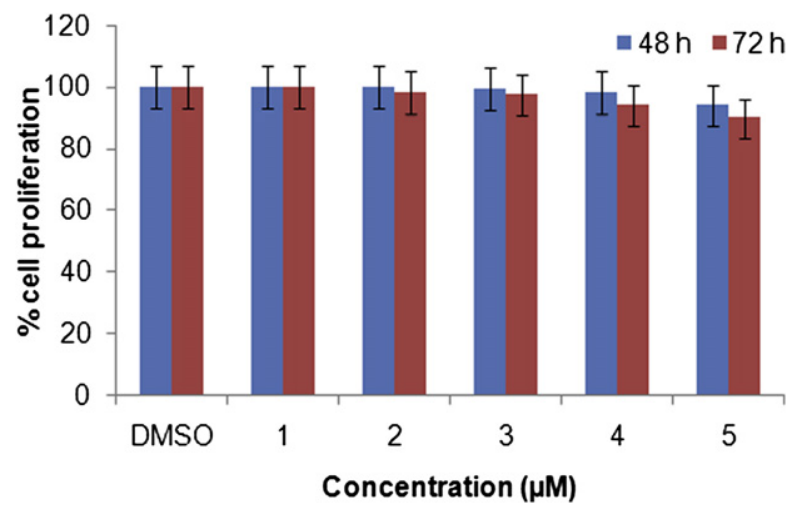

Fig. 3. Effect of $4 \mathbf{e}$ on the growth of normal cells. 293T cells exposed to different concentrations of $\mathbf{4 e}$ were incubated with MTT and absorbance was measured at $570 \mathrm{~nm}$. (1eq) were added at cold condition and stirred at room temperature for $6-8 \mathrm{~h}$ (completion of reaction was confirmed by TLC). After completion of the reaction, the reaction mixture was concentrated and water was added and extracted thrice using ethyl acetate. The combined ethyl acetate layer was washed with brine solution and dried over anhydrous sodium sulphate. Ethyl acetate was evaporated under reduced pressure and the crude product obtained was purified by silica gel (60-120 mesh) column to get the compounds 3 $(\mathbf{a}-\mathbf{h})$. To the solution of compound $\mathbf{3}(\mathbf{a}-\mathbf{h})$ in dry ether $(3 \mathrm{~mL})$ at $0{ }^{\circ} \mathrm{C}$ saturated $\mathrm{HCl}$ in ether $(1 \mathrm{ml})$ was added slowly and stirred at $0^{\circ} \mathrm{C}$ for $3 \mathrm{~h}$, white solid formed was filtered and dried under vaccum to get the compounds $\mathbf{4}(\mathbf{a}-\mathbf{h})$.

6.1.2.1. Synthesis of (S)-N-(6-amino-4,5,6,7-tetrahydrobenzo[d]thiazol-2-yl)benzamide hydrochloride $\mathbf{4 a}$. The product $\mathbf{4 a}$ was obtained by reaction of compound $2(0.40 \mathrm{~g}, 1.5 \mathrm{mmol})$ with benzoyl chloride $(0.21 \mathrm{~g}, 1.5 \mathrm{mmol})$ and triethylamine $(0.45 \mathrm{~g}, 4.5 \mathrm{~mol})$ in dichloromethane $(5 \mathrm{ml})$ and then cleaving the Boc protection using $\mathrm{HCl}$ in ether using the general experimental procedure as described. Yield $0.35 \mathrm{~g}(76 \%)$. IR $\left(\mathrm{KBr}, \mathrm{cm}^{-1}\right): 1688 .{ }^{1} \mathrm{H}$ NMR (DMSO-d 6 , $\left.400 \mathrm{MHz}\right) \delta$ : 12.41 (bs, $1 \mathrm{H}, \mathrm{NH}$ ), 8.44 (d, 3H, NH${ }_{3}^{+}$salt), 7.65 ( $\mathrm{m}, 5 \mathrm{H}, \mathrm{Ar}-\mathrm{H}$ ), 3.53 (bs, $1 \mathrm{H},-\mathrm{CH}-), 3.14-3.09\left(\mathrm{~m}, 1 \mathrm{H},-\mathrm{CH}_{2}-\right), 2.83-2.75\left(\mathrm{~m}, 1 \mathrm{H},-\mathrm{CH}_{2}-\right)$, 2.73-2.65 ( $\left.\mathrm{m}, 2 \mathrm{H},-\mathrm{CH}_{2}-\right), 2.19\left(\mathrm{t}, 1 \mathrm{H},-\mathrm{CH}_{2}-\right), 1.98\left(\mathrm{t}, 1 \mathrm{H},-\mathrm{CH}_{2}-\right.$ ). MS (ESI + ion): $m / z=310.2$. Elemental Analysis: Found: C, 54.34; $\mathrm{H}$, 5.27; N, 13.65; S, 10.22; Calculated for $\mathrm{C}_{14} \mathrm{H}_{16} \mathrm{ClN}_{3} \mathrm{OS}$ : C, 54.27; $\mathrm{H}$, $5.21 ; \mathrm{N}, 13.56 ; \mathrm{S}, 10.35$.

6.1.2.2. Synthesis of (S)-N-(6-amino-4,5,6,7-tetrahydrobenzo[d]thiazol-2-yl)-3-methoxy benzamide hydrochloride $\mathbf{4 b}$. The product $\mathbf{4 b}$ was obtained by reaction of compound $2(0.40 \mathrm{~g}, 1.5 \mathrm{mmol})$ with 3 methoxy benzoyl chloride $(0.26 \mathrm{~g}, 1.5 \mathrm{mmol})$ and triethylamine $(0.45 \mathrm{~g}, 4.5 \mathrm{~mol})$ in dichloromethane $(5 \mathrm{ml})$ and then cleaving the Boc 
protection using $\mathrm{HCl}$ in ether using the general experimental procedure as described. Yield $0.40 \mathrm{~g}(78 \%)$. IR $\left(\mathrm{KBr}, \mathrm{cm}^{-1}\right): 1690,1237,1112$. ${ }^{1} \mathrm{H}$ NMR (DMSO- $\left.d_{6}, 400 \mathrm{MHz}\right) \delta: 12.48$ (bs, $\left.1 \mathrm{H}, \mathrm{NH}\right), 8.49$ (d, 3H, $\mathrm{NH}_{3}^{+}$ salt), 7.65 (m, 1H, Ar-H), 7.44 (m, 2H, Ar-H), $7.12(\mathrm{~s}, 1 \mathrm{H}, \mathrm{Ar}-\mathrm{H}), 3.92(\mathrm{~s}$, $\left.3 \mathrm{H},-\mathrm{OCH}_{3}\right), 3.57(\mathrm{bs}, 1 \mathrm{H},-\mathrm{CH}-), 3.13-3.09\left(\mathrm{~m}, 1 \mathrm{H},-\mathrm{CH}_{2}-\right), 2.8-2.76$ $\left(\mathrm{m}, 1 \mathrm{H},-\mathrm{CH}_{2}-\right), 2.71-2.64\left(\mathrm{~m}, 2 \mathrm{H},-\mathrm{CH}_{2}-\right), 2.18\left(\mathrm{t}, 1 \mathrm{H},-\mathrm{CH}_{2}-\right), 1.96$ $\left(\mathrm{t}, 1 \mathrm{H},-\mathrm{CH}_{2}-\right.$ ). MS (ESI + ion): $m / z=340.3$. Elemental Analysis: Found: $\mathrm{C}, 52.91 ; \mathrm{H}, 5.36 ; \mathrm{N}, 12.42 ; \mathrm{S}, 9.37$; Calculated for $\mathrm{C}_{15} \mathrm{H}_{18} \mathrm{ClN}_{3} \mathrm{O}_{2} \mathrm{~S}$ : C, 53.01; H, 5.34; N, 12.36; S, 9.44.

6.1.2.3. Synthesis of (S)-N-(6-amino-4,5,6,7-tetrahydrobenzo[d]thiazol-2-yl)-2-fluorobenzamide hydrochloride $\mathbf{4 c}$. The product $\mathbf{4 c}$ was obtained by reaction of compound $2(0.40 \mathrm{~g}, 1.5 \mathrm{mmol})$ with 2fluoro benzoyl chloride $(0.24 \mathrm{~g}, 1.5 \mathrm{mmol})$ and triethylamine $(0.45 \mathrm{~g}, 4.5 \mathrm{mmol})$ in dichloromethane $(5 \mathrm{ml})$ and then cleaving the Boc protection using $\mathrm{HCl}$ in ether using the general experimental procedure as described. Yield $0.37 \mathrm{~g}(75 \%)$.

IR $\left(\mathrm{KBr}, \mathrm{cm}^{-1}\right): 1688,1033 .{ }^{1} \mathrm{H}$ NMR (DMSO- $\left.d_{6}, 400 \mathrm{MHz}\right) \delta: 12.41$ (bs, $1 \mathrm{H}, \mathrm{NH}$ ), 8.41 (d, 3H, $\mathrm{NH}_{3}^{+}$salt), 7.74-7.69 (m, 1H, Ar-H), 7.65-7.59 (m, 1H, Ar-H), 7.38-7.32 (m, 2H, Ar-H), 3.53 (bs, 1H, - CH-), 3.15-3.09 $\left(\mathrm{m}, 1 \mathrm{H},-\mathrm{CH}_{2}-\right), 2.83-2.77\left(\mathrm{~m}, 1 \mathrm{H},-\mathrm{CH}_{2}-\right), 2.73-2.64(\mathrm{~m}$, $\left.2 \mathrm{H},-\mathrm{CH}_{2}-\right), 2.17\left(\mathrm{t}, 1 \mathrm{H},-\mathrm{CH}_{2}-\right), 1.97\left(\mathrm{t}, 1 \mathrm{H},-\mathrm{CH}_{2}-\right)$. MS (ESI + ion): $m / z=328.1$. Elemental Analysis: Found: $\mathrm{C}, 51.36 ; \mathrm{H}, 4.54 ; \mathrm{N}, 12.88 ; \mathrm{S}$, 9.75; Calculated for $\mathrm{C}_{14} \mathrm{H}_{15} \mathrm{ClFN}_{3} \mathrm{OS}$ : C, 51.30; $\mathrm{H}, 4.61 ; \mathrm{N}, 12.82 ; \mathrm{S}, 9.78$.

6.1.2.4. Synthesis of (S)-N-(6-amino-4,5,6,7-tetrahydrobenzo[d]thiazol-2-yl)-3-bromobenzamide hydrochloride $4 \boldsymbol{d}$. The product 4d was obtained by reaction of compound $2(0.40 \mathrm{~g}, 1.5 \mathrm{mmol})$ with 3bromo benzoyl chloride $(0.33 \mathrm{~g}, 1.5 \mathrm{mmol})$ and triethylamine $(0.45 \mathrm{~g}, 4.5 \mathrm{mmol})$ in dichloromethane $(5 \mathrm{ml})$ and then cleaving the Boc protection using $\mathrm{HCl}$ in ether using the general experimental procedure as described. Yield $0.38 \mathrm{~g}$ (67\%).

IR $\left(\mathrm{KBr}, \mathrm{cm}^{-1}\right): 1686,688 .{ }^{1} \mathrm{H}$ NMR (DMSO- $\left.d_{6}, 400 \mathrm{MHz}\right) \delta: 12.41$ (bs, $1 \mathrm{H}, \mathrm{NH}), 8.41$ (d, 3H, $\mathrm{NH}_{3}^{+}$salt), $7.76(\mathrm{~m}, 1 \mathrm{H}, \mathrm{Ar}-\mathrm{H}), 7.52(\mathrm{~m}, 2 \mathrm{H}$, Ar-H), 7.34 (s, 1H, Ar-H), 3.50 (bs, $1 \mathrm{H},-\mathrm{CH}-), 3.17-3.11(\mathrm{~m}, 1 \mathrm{H}$, $\left.-\mathrm{CH}_{2}-\right), 2.83-2.77\left(\mathrm{~m}, 1 \mathrm{H},-\mathrm{CH}_{2}-\right), 2.75-2.65\left(\mathrm{~m}, 2 \mathrm{H},-\mathrm{CH}_{2}-\right), 2.19$ (t, $\left.1 \mathrm{H},-\mathrm{CH}_{2}-\right), 1.95\left(\mathrm{t}, 1 \mathrm{H},-\mathrm{CH}_{2}-\right.$ ). MS (ESI + ion): $m / z=389.0$. Elemental Analysis: Found: C, 43.29; H, 3.86; N, 10.89; S, 8.15; Calculated for $\mathrm{C}_{14} \mathrm{H}_{15} \mathrm{BrClN}_{3} \mathrm{OS}$ : C, 43.26; $\mathrm{H}, 3.89 ; \mathrm{N}, 10.81 ; \mathrm{S}, 8.25$.

6.1.2.5. Synthesis of (S)-N-(6-amino-4,5,6,7-tetrahydrobenzo[d]thiazol-2-yl)-4-tert-butylbenzamide hydrochloride $\mathbf{4 e}$. The product $\mathbf{4 e}$ was obtained by reaction of compound $2(0.40 \mathrm{~g}, 1.5 \mathrm{mmol})$ with 4tert-butyl benzoyl chloride $(0.30 \mathrm{~g}, 1.5 \mathrm{mmol})$ and triethylamine $(0.45 \mathrm{~g}, 4.5 \mathrm{mmol})$ in dichloromethane $(5 \mathrm{ml})$ and then cleaving the Boc protection using $\mathrm{HCl}$ in ether using the general experimental procedure as described. Yield $0.44 \mathrm{~g}(79 \%)$.

IR $\left(\mathrm{KBr}, \mathrm{cm}^{-1}\right): 1684,1399 .{ }^{1} \mathrm{H}$ NMR (DMSO- $\left.d_{6}, 400 \mathrm{MHz}\right) \delta: 12.41$ (bs, $1 \mathrm{H}, \mathrm{NH}), 8.41$ (d, 3H, NH $\mathrm{N}_{3}^{+}$salt), $7.79(\mathrm{~d}, 2 \mathrm{H}, \mathrm{Ar}-\mathrm{H}), 7.54$ (d, 2H, Ar$\mathrm{H}), 3.53$ (bs, $1 \mathrm{H},-\mathrm{CH}-$ ), $3.14-3.09\left(\mathrm{~m}, 1 \mathrm{H},-\mathrm{CH}_{2}-\right), 2.84-2.76(\mathrm{~m}$, $\left.1 \mathrm{H},-\mathrm{CH}_{2}-\right), 2.71-2.62\left(\mathrm{~m}, 2 \mathrm{H},-\mathrm{CH}_{2}-\right), 2.15\left(\mathrm{t}, 1 \mathrm{H},-\mathrm{CH}_{2}-\right), 1.99(\mathrm{t}$, $\left.1 \mathrm{H},-\mathrm{CH}_{2}-\right), 1.33\left(\mathrm{~s}, 9 \mathrm{H},\left(-\mathrm{CH}_{3}\right)_{3}\right)$. MS (ESI + ion $): m / z=366.2$. Elemental Analysis: Found: C, 59.14; H, 6.66; N, 11.42; S, 8.69.; Calculated for $\mathrm{C}_{18} \mathrm{H}_{24} \mathrm{ClN}_{3} \mathrm{OS}$ : C, 59.08; $\mathrm{H}, 6.61 ; \mathrm{N}, 11.48 ; \mathrm{S}, 8.76$.

6.1.2.6. Synthesis of (S)-N-(6-amino-4,5,6,7-tetrahydrobenzo[d]thiazol-2-yl)-2,6-difluoro benzamide hydrochloride $\mathbf{4 f}$. The product $\mathbf{4 f}$ was obtained by reaction of compound $2(0.40 \mathrm{~g}, 1.5 \mathrm{mmol})$ with 2,6-difluoro benzoyl chloride $(0.27 \mathrm{~g}, 1.5 \mathrm{mmol})$ and triethylamine ( $0.45 \mathrm{~g}, 4.5 \mathrm{mmol})$ in dichloromethane $(5 \mathrm{ml})$ and then cleaving the Boc protection using $\mathrm{HCl}$ in ether using the general experimental procedure as described. Yield $0.41 \mathrm{~g}(78 \%)$. IR $\left(\mathrm{KBr}, \mathrm{cm}^{-1}\right): 1689$, 1167. ${ }^{1} \mathrm{H}$ NMR (DMSO- $\left.d_{6}, 400 \mathrm{MHz}\right) \delta: 12.45$ (bs, $\left.1 \mathrm{H}, \mathrm{NH}\right), 8.46$ (d, $3 \mathrm{H}, \mathrm{NH}_{3}^{+}$salt), $7.65(\mathrm{~m}, 1 \mathrm{H}, \mathrm{Ar}-\mathrm{H}), 7.26$ (t, 2H, Ar-H), 3.53 (bs, $1 \mathrm{H}$, $-\mathrm{CH}-)$, 3.16-3.10 (m, $\left.1 \mathrm{H},-\mathrm{CH}_{2}-\right), 2.85-2.79\left(\mathrm{~m}, 1 \mathrm{H},-\mathrm{CH}_{2}-\right)$, $2.77-2.67\left(\mathrm{~m}, 2 \mathrm{H},-\mathrm{CH}_{2}-\right), 2.17\left(\mathrm{t}, 1 \mathrm{H},-\mathrm{CH}_{2}-\right), 1.98\left(\mathrm{t}, 1 \mathrm{H},-\mathrm{CH}_{2}-\right)$. MS (ESI + ion): $m / z=346.1$. Elemental Analysis: Found: $\mathrm{C}, 48.52 ; \mathrm{H}$, 3.97; N, 12.11; S, 9.19; Calculated for $\mathrm{C}_{14} \mathrm{H}_{14} \mathrm{ClF}_{2} \mathrm{~N}_{3} \mathrm{OS}$ : C, 48.63; $\mathrm{H}$, $4.08 ; \mathrm{N}, 12.15 ; \mathrm{S}, 9.27$.

6.1.2.7. Synthesis of (S)-N-(6-amino-4,5,6,7-tetrahydrobenzo[d]thiazol-2-yl)-3,5-dinitro benzamide hydrochloride $\mathbf{4 g}$. The product $\mathbf{4 g}$ was obtained by reaction of compound $2(0.40 \mathrm{~g}, 1.5 \mathrm{mmol})$ with 3,5-dinitro benzoyl chloride $(0.34 \mathrm{~g}, 1.5 \mathrm{mmol})$ and triethylamine $(0.45 \mathrm{~g}, 4.5 \mathrm{~mol})$ in dichloromethane $(5 \mathrm{ml})$ and then cleaving the Boc protection using $\mathrm{HCl}$ in ether using the general experimental procedure as described. Yield $0.47 \mathrm{~g}(78 \%)$. IR $\left(\mathrm{KBr}, \mathrm{cm}^{-1}\right): 1690$, 1545,1338. ${ }^{1} \mathrm{H}$ NMR (DMSO-d $6,400 \mathrm{MHz}$ ) $\delta: 12.49$ (bs, $1 \mathrm{H}, \mathrm{NH}$ ), 8.59 (s, 2H, Ar-H), 7.48 (s, 1H, Ar-H), 8.39 (d, 3H, NH ${ }_{3}^{+}$salt), 3.53 (bs, $1 \mathrm{H},-\mathrm{CH}-)$, 3.19-3.12 ( $\left.\mathrm{m}, 1 \mathrm{H},-\mathrm{CH}_{2}-\right), 2.85-2.78\left(\mathrm{~m}, 1 \mathrm{H},-\mathrm{CH}_{2}-\right)$, 2.74-2.66 ( $\left.\mathrm{m}, 2 \mathrm{H},-\mathrm{CH}_{2}-\right), 2.18\left(\mathrm{t}, 1 \mathrm{H},-\mathrm{CH}_{2}-\right), 1.97\left(\mathrm{t}, 1 \mathrm{H},-\mathrm{CH}_{2}-\right)$. MS (ESI + ion): $m / z=400.1$. Elemental Analysis: Found: C, $42.014 \mathrm{H}$, 3.47; N, 17.58; S, 7.93.; Calculated for $\mathrm{C}_{14} \mathrm{H}_{14} \mathrm{ClN}_{5} \mathrm{O}_{5} \mathrm{~S}$ : C, 42.06; $\mathrm{H}$, $3.53 ; \mathrm{N}, 17.52 ; \mathrm{S}, 8.02$.

6.1.2.8. Synthesis of (S)-N-(6-amino-4,5,6,7-tetrahydrobenzo[d]thiazol-2-yl)-2,4-dichloro benzamide hydrochloride $\mathbf{4 h}$. The product $\mathbf{4 h}$ was obtained by reaction of compound $2(0.40 \mathrm{~g}, 1.5 \mathrm{mmol})$ with 2,4-dichloro benzoyl chloride $(0.31 \mathrm{~g}, 1.5 \mathrm{mmol})$ and triethylamine $(0.45 \mathrm{~g}, 4.5 \mathrm{mmol})$ in dichloromethane $(5 \mathrm{ml})$ and then cleaving the Boc protection using $\mathrm{HCl}$ in ether as given in general procedure. Yield $0.39 \mathrm{~g}(68 \%)$. IR $\left(\mathrm{KBr}, \mathrm{cm}^{-1}\right)$ : $1686,722 .{ }^{1} \mathrm{H}$ NMR (DMSO- $\left.d_{6}, 400 \mathrm{MHz}\right) \delta: 12.47$ (bs, $\left.1 \mathrm{H}, \mathrm{NH}\right), 8.39$ (d, 3H, $\mathrm{NH}_{3}^{+}$salt), 7.39 (s, 1H, Ar-H), 7.23 (m, 2H, Ar-H), 3.49 (bs, $1 \mathrm{H},-\mathrm{CH}-$ ), 3.16-3.11 (m, $\left.1 \mathrm{H},-\mathrm{CH}_{2}-\right), 2.84-2.75\left(\mathrm{~m}, 1 \mathrm{H},-\mathrm{CH}_{2}-\right), 2.75-2.67$ $\left(\mathrm{m}, 2 \mathrm{H},-\mathrm{CH}_{2}-\right), 2.14\left(\mathrm{t}, 1 \mathrm{H},-\mathrm{CH}_{2}-\right), 1.99\left(\mathrm{t}, 1 \mathrm{H},-\mathrm{CH}_{2}-\right) . \mathrm{MS}$ $(\mathrm{ESI}+$ ion $): m / z=379.0$. Elemental Analysis: Found: $\mathrm{C}, 44.37 ; \mathrm{H}$, 3.60; N, 11.21; S, 8.41; Calculated for $\mathrm{C}_{14} \mathrm{H}_{14} \mathrm{Cl}_{3} \mathrm{~N}_{3} \mathrm{OS}$ : C, 44.40; $\mathrm{H}$, 3.73; N, 11.10; S, 8.47.

\subsection{Biological study}

The human chronic myelogenous leukemia (CML) K562 and CEM were selected for the purpose of preliminary anti-cancer screening of newly synthesized compounds. To assess the cytotoxicity, we employed trypan blue dye exclusion assay, MTT assay, LDH assay and FACS analysis. For this, cells growing in log phase were treated with different concentrations (as mentioned in respective assays) of 4,5,6,7-tetrahydrobenzo[d]thiazole derivatives $\mathbf{4}(\mathbf{a}-\mathbf{h})$. Assays were carried out in duplicate in at least three independent experiments.

\subsubsection{Cell lines and culture}

Human cell lines, K562 and CEM were purchased from National Center for Cell Science, Pune, India. Cells were grown in RPMI 1640 supplemented with $10 \%$ heat-inactivated fetal bovine serum (FBS), $100 \mathrm{U} / \mathrm{mL}$ of Penicillin, and $100 \mu \mathrm{g}$ of streptomycin $/ \mathrm{ml}$ and incubated at $37{ }^{\circ} \mathrm{C}$ in a humidified atmosphere containing $5 \% \mathrm{CO}_{2}$.

\subsubsection{Trypan blue exclusion assay}

Cell viability was monitored by the Trypan blue exclusion assay as reported earlier [25]. Briefly, K562 or CEM cells, growing in exponential phase were seeded at a density of $0.75 \times 10^{5}$ cells/ $\mathrm{ml}$ in a 6-well tissue culture plate for $24 \mathrm{~h}$ and cells were exposed to a different concentrations $(10,50$, and $100 \mu \mathrm{M})$ of 4 $(\mathbf{a}-\mathbf{h})$. Cells were collected at intervals of $24 \mathrm{~h}$ and resuspended in $0.4 \%$ Trypan blue and further incubated for 5 min after which the number of viable cells was estimated in a haemocytometer chamber. 


\subsubsection{MTT assay}

Cell proliferation was further assessed by 3-(4,5-dimethylthiazol-2-yl)-2,5-diphenyl tetrazolium bromide (MTT) assay, which is based on the ability of viable cells to metabolize a yellow tetrazolium salt to violet formazan. Exponentially growing K562 or CEM cells $\left(1 \times 10^{4}\right.$ cells/well) were plated in duplicates and incubated with 10,50 and $100 \mu \mathrm{M}$ of $\mathbf{4}(\mathbf{a}-\mathbf{h})$. Cells were harvested after 48 and $72 \mathrm{~h}$ of treatment and incubated with MTT $(0.5 \mathrm{mg} / \mathrm{ml})$. The percentage cell proliferation was calculated and $\mathrm{IC}_{50}$ values (concentration of compound causing 50\% inhibition of cell growth) were estimated after $72 \mathrm{~h}$ of compound treatment.

\subsection{4. $\mathrm{LDH}$ release assay}

The cytotoxicity of the compound $\mathbf{4 e}$ was further assessed by $\mathrm{LDH}$ release assay, which is an indicator of membrane integrity and hence cell injury. LDH assay was performed as per standard protocols [26] to estimate the LDH release in the culture media following the treatment of $4 \mathbf{e}$ at 1,5 and $10 \mu \mathrm{M}$ concentrations on K562 cells for $24 \mathrm{~h}$. The LDH release was measured. Percentage of LDH release was calculated and plotted as graph as shown in Fig. 1.

\subsubsection{Cell cycle analysis}

Cellular DNA content of K562 cells followed by $4 \mathbf{e}$ treatment was measured by flow cytometry. Approximately $0.75 \times 10^{5}$ cells $/ \mathrm{ml}$ were cultured and treated with 1,5 and $10 \mu \mathrm{M}$ concentrations of $4 \mathbf{e}$. Cells were harvested after $24 \mathrm{~h}$ of treatment, washed, fixed in $70 \%$ ethanol and incubated with RNase A (Sigma-Aldrich, USA). Propidium iodide (PI, $50 \mu \mathrm{g} / \mathrm{ml}$, Sigma-Aldrich, USA) was added half an hour before acquiring the flow cytometric reading (FACScan, BD Biosciences, USA). A minimum of 10,000 cells were acquired per sample and histograms were analyzed by using WinMDI 2.8 software.

\section{Acknowledgements}

We are grateful to UGC, Govt. of India for financial support to KSR under the projects vide no. F. 31-143/2005(SR), UGC-SAP (Phase II) vide No.F. 540/10/2004-05 (SAP -DRS-II). SCR acknowledges support from Lady Tata Memorial Trust international award for leukemia research (London). DSP is grateful to Council of Scientific and Industrial Research, New Delhi for financial support under CSIR-SRF order No. 09/119(0173)2K8 EMR-I

\section{References}

[1] T. Shimamura, J. Shibata, H. Kurihara, T. Mita, S. Otsuki, T. Sagara, H. Hirai, Y. Iwasawa, Bioorg. Med. Chem. Lett. 16 (2006) 3751-3754.

[2] C.J. Helal, M.A. Sanner, C.B. Cooper, T. Gant, M. Adam, J.C. Lucas, Z. Kang, S. Kupchinsky, M.K. Ahlijanian, B. Tate, F.S. Menniti, K. Kelly, M. Peterson, Bioorg. Med. Chem. Lett. 14 (2004) 5521-5525.

[3] C. Zhou, L. Guo, W.H. Parsons, S.G. Mills, M. MacCoss, P.P. Vicario, H. Zweerink M.A. Cascieri, M.S. Springer, L. Yang, Bioorg. Med. Chem. Lett. 17 (2007) 309-314.

[4] X. Wang, F. Xu, Q. Xu, H. Mahmud, J. Houze, L. Zhu, M. Akerman, G. Tonn, L. Tang, B.E. McMaster, D.J. Dairaghi, T.J. Schall, T.L. Collins, J.C. Medina, Bioorg. Med. Chem. Lett. 16 (2006) 2800-2803.

[5] N.J. Press, R.J. Taylor, J.D. Fullerton, P. Tranter, C. McCarthy, T.H. Keller L. Brown, R. Cheung, J. Christie, S. Haberthuer, J.D.I. Hatto, M. Keenan, M.K. Mercer, N.E. Press, H. Sahri, A.R. Tuffnell, M. Tweed, J.R. Fozard, Bioorg. Med. Chem. Lett. 15 (2005) 3081-3085.

[6] A.G. Cole, T.M. Stauffer, L.L. Rokosz, A. Metzger, L.W. Dillard, W. Zeng, I. Henderson, Bioorg. Med. Chem. Lett. 19 (2009) 378-381.

[7] M.D. Chordia, L.J. Murphree, T.L. Macdonald, J. Linden, R.A. Olsson, Bioorg Med. Chem. Lett. 12 (2002) 1563-1566.

[8] K.Y. Jung, S.K. Kim, Z.G. Gao, A.S. Gross, N. Melman, K.A. Jacobson, Y.C. Kim, Bioorg. Med. Chem. 12 (2004) 613-623.

[9] O. Kouatly, A. Geronikaki, C. Kamoutsis, D.H. Litina, P. Eleftheriou, Eur. J. Med Chem. 44 (2009) 1198-1204.

[10] K. Yamawaki, T. Nomura, T. Yasukata, K. Uotani, H. Miwa, K. Takeda, Y. Nishitani, Bioorg. Med. Chem. 15 (2007) 6716-6732.

[11] I. Hutchinson, T.D. Bradshaw, C.S. Matthews, M.F.G. Stevens, A.D. Westwell, Bioorg. Med. Chem. Lett. 13 (2003) 471-474.

[12] I. Hutchinson, S.A. Jennings, B.R. Vishnuvajjala, A.D. Westwell, M.F.G. Stevens, J. Med. Chem. 45 (2002) 744-747.

[13] P.Y. Lin, S.J. Shi, H.L. Shu, H.F. Chen, C.C. Lin, P.C. Liu, L.F. Wang, Bioorg. Chem. 28 (2000) 266-272.

[14] I.H. Hall, N.J. Peaty, J.R. Henry, J. Easmon, G. Heinisch, G. Purstinger, Arch. Pharm. (Weinheim) 332 (1999) 115-130.

[15] V. Beneteau, T. Besson, J. Guillard, S. Leonce, B. Pfeiffer, Eur. J. Med. Chem. 34 (1999) 1053-1060.

[16] T.D. Bradshaw, S. Wrigley, D.F. Shi, R.J. Schultz, K.D. Paull, M.F.G. Stevens, Br. J Cancer 77 (1998) 745-752.

[17] M.J. Gorczynski, R.M. Leal, S.L. Mooberry, J.H. Bushweller, M.L. Brown, Bioorg. Med. Chem. 12 (2004) 1029-1036.

[18] N.P. Shah, C. Tran, F.Y. Lee, P. Chen, D. Norris, C.L. Sawyers, Science 305 (2004) 399-401.

[19] L.J. Lombardo, F.Y. Lee, P. Chen, D. Norris, J.C. Barrish, K. Behnia, S. Castaneda, L.A.M. Cornelius, J. Das, A.M. Doweyko, C. Fairchild, J.T. Hunt, I. Inigo, K. Johnston, A. Kamath, D. Kan, H. Klei, P. Marathe, S. Pang, R. Peterson, S. Pitt G.L. Schieven, R.J. Schmidt, J. Tokarski, M.L. Wen, J. Wityak, R.M. Borzilleri, J. Med. Chem. 47 (2004) 6658-6661.

[20] M. Copland, A. Hamilton, L.J. Elrick, J.W. Baird, E.K. Allan, N. Jordanides, M. Barow, J.C. Mountford, T.L. Holyoake, Blood 107 (2006) 4532-4539.

[21] J.A. McIntyre, J. Castaner, M. Bayes, Drugs Future 31 (2006) 291-371.

[22] D.S. Prasanna, C.V. Kavitha, B. Raghava, K. Vinaya, S.R. Ranganatha, S.C. Raghavan, K.S. Rangappa, Invest. New Drugs 28 (2010) 454-465.

[23] D.S. Prasanna, C.V. Kavitha, K. Vinaya, S.R. Ranganatha, B. Raghava, Y.C. Sunil Kumar, S.C. Raghavan, K.S. Rangappa, Bull. Chem. Soc. Jpn. 83 (2010) 689-697.

[24] C.S. Schneider, J. Mierau, J. Med. Chem. 30 (1987) 494-498.

[25] C.V. Kavitha, M. Nambiar, C.S. Ananda Kumar, B. Choudhary, K. Muniyappa, K.S. Rangappa, S.C. Raghavan, Biochem. Pharmacol. 77 (2009) 348-363.

[26] C. Korzeniewski, D.M. Callewaert, J. Immunol. Methods 64 (1983) 313-320. 